\title{
Viták a hazai pénzügyi felügyelés megújításáról a 20. század elsó felében ${ }^{1}$
}

\section{Debates about the Revitalisation of Financial Supervision in the First Half of the 20th Century}

\section{Összefoglalás}

Jelen tanulmány a pénzügyi felügyelés kialakítását és gyakorlatának fejlesztését érintô fontosabb szakmai viták bemutatását túzi ki célul, elsôsorban a 20. század elsô felére helyezve a hangsúlyt. A szerzố arra keresi a választ, hogy milyen fontosabb viták vezettek el a felügyelés megújításához, ezek milyen eredményre vezettek, továbbá milyen javaslatokat nem fogadtak el valamilyen okból kifolyólag. A viták középpontjában elsôsorban a Pénzintézeti Központ tevékenysége állt, ugyanakkor ezen keresztül nyilvánvalóan a teljes felügyeleti tevékenység megújítására vonatkozó kezdeményezések is kifejezésre jutottak. A tanulmány arra törekszik, hogy az ismertetett vitákat megfelelô kontextusba helyezze, hiszen az álláspontok nem függetleníthetôk a gazdasági-társadalmi folyamatoktól, annak ismeretében szükséges azokat értékelnünk.

Journal of Economic Literature (JEL) kódok: B10, G28, N24, N94

Kulcsszavak: pénzintézetek, pénzügyi felügyelés, Pénzintézeti Központ, szakmai viták

VARGa Bence PhD, vezetô felügyeló, Magyar Nemzeti Bank (vargabe@mnb.hu). 
Polgári Szemle $\cdot$ 16. évfolyam 4-6. szám

\section{Summary}

This study aims to present the most significant professional debates concerning the elaboration and development of financial supervision, focusing on the first half of the 20th century. The author seeks to identify the major debates that led to the renewal of supervision, the outcomes of these debates, and the proposals that were refused. These discussions focused mainly on the activity of the Centre for Financial Institutions, but at the same time, initiatives were taken to renew the complete supervisory activity. The study seeks to place the described debates in an appropriate context, as the various approaches are inseparable from and should be evaluated on the basis of the social and economic developments.

Journal of Economic Literature (JEL) codes: B10, G28, N24, N94

Keywords: financial institutions, financial supervision, Centre for Financial Institutions, professional debates

\section{BEVEZETÉS}

Több mint hét évtizednek kellett eltelni az elsô hazai bank megalapításától az elsô integrált felügyeleti szerv, a Pénzintézeti Központ 1916-ban történt létrejöttéig. Megalapítását hosszas szakmai viták, egyeztetések előzték meg, melyek nagyban hozzájárultak a felügyelés sikerességéhez, hiszen a két világháború között a hazai pénzügyi felügyelés hatékonyan tudott reagálni a bel- és külgazdasági eseményekre, a helyszíni vizsgálatok gyakorisága emelkedett, a Pénzintézeti Központ felügyelési szerepe erôsödött, az ellenőrzés mind szélesebb intézményi kört ölelt fel (Kovács-Varga, 2018; Lentner, 2019).

Felügyeleti szerv ugyan más országokban már hazánkat megelőzóen is alakult, illetôleg felügyeleti elődszervezetek nálunk is létrejöttek korábban, a felügyeléshez kapcsolható szanálási funkció korai bevezetése azonban mindenképpen egyedülálló a bankrendszerek történetében. A Pénzintézeti Központ 1916. évi létrehozatala, múködésének keretei a 20. század elsố felében sem jelentettek végleges állapotot, azok az évek során a késôbbiekben folyamatosan alakultak, változtak (Varga, 2016a), melyek kapcsán szintén kiemelt fontossággal bírtak a különbözó fórumokon lezajló szakmai viták. Ezek is nagyban hozzájárulhattak ahhoz, hogy a pénzügyi felügyelés az elmúlt mintegy száz év során folyamatosan fejlődött mind intézményrendszerét, mind módszertanát, szemléletét tekintve (Kandrács, 2019).

VITÁK A PÉNZÜGYI FELÜGYELÉS MEGÚJítÁSÁRÓL A Pénzintézeti KözPONT Létrejöttét MEgelốzónen

A Pénzintézeti Központ megalakulását megelôzôen számos, különböző fórumokon lezajló szakmai vitára került sor, és a közgazdasági gondolkodásban egymással ellentétes vélemények alakultak ki. Például a takarékpénztárak esetében merültek fel a jelenlegi 
felügyeleti gyakorlat alapján meglehetôsen szigorúnak tekinthetô, olyan külsố szerv általi felügyelést szorgalmazó javaslatok, melyek célként túzték ki az üzletági korlátozás bevezetését (Varga, 2016b). Így különösen a visszleszámítolás megtiltására született javaslat, illetôleg hogy a betéteket kizárólag állampapírokba vagy záloglevelekbe lehessen elhelyezni. Ezt a direkt típusú központi szabályozást utasította el Székely Ferenc (1890) késôbbi igazságügyi miniszter, mondván, hogy az üzletági korlátozás helyett inkább a szabályozottság növelése lenne kívánatos. Blum Brúnó (1899:763), a Budapesti Bankegyesület fốtisztviselôje is rámutatott a hazai önálló szabályozás kidolgozásának fontosságára, ti. itt „új, minden ízében magyar múvet kell alkotni”. Kevésbé direkt, megengedóbb szabályozás kialakítása mellett foglalt állást Sugár Ignác (1899), a miskolci kereskedelmi és iparkamara akkori titkára. Ố a pénzintézetek betétkezelési, váltóleszámítolási és visszleszámítolási gyakorlatába, jelzálogkölcsön-üzletágába történô beavatkozást nemcsak hibás elgondolásnak tartotta, hanem annak megvalósíthatóságát is megkérdőjelezte. Ezzel szemben a figyelmet a vállalatirányítás és ügyvezetés ellenôrzésére, valamint hozzáértő felügyelő szakértők kinevelésének fontossága felé fordította.

A felügyelés szükségességét kérdőjelezte meg többek között ifj. Andrássy Gyula korábbi belügyminiszter, majd késôbb rövid ideig külügyminiszter, aki a Pénzintézeti Központ létrehozása céljából, múködésének újszerúségéból, reformvoltából kiindulva cáfolta meg annak szükségességét. Érvelése szerint nem lehet szükség olyan reformra, amely más államokban nem terjedt el. A felügyelés szükségességével kapcsolatos vita nemcsak hazai, hanem nemzetközi szinten egyaránt tapasztalható volt, Jakob Riesser korabeli meghatározó német politikus az állami felügyelet meghonosításának javaslata kapcsán egyenesen károsnak értékelte az állami felügyeletek múködését. Azok ugyanis - véleménye szerint - indokolatlan bizalmat ébresztenek a betétesek körében, megbízható megállapítások megtételére pedig nem alkalmasak (Jakabb et al., 1941). Hasonló következtetésre jutott Hantos Elemér (1916), a Pénzintézetek Országos Egyesületének elnöke is, értékelve a pénzügyi felügyelés kialakítása iránti hazai és külföldi „reformmozgalmakat”, egyaránt kétségbe vonva az állami ellenôrzés célját és jogosultságát.

A Pénzintézeti Központ létrehozásához szükséges összeg tekintetében szintén nem mutatkozott egyetértés. Sümegi Vilmos országgyúlési képviselő a 25 millió korona veszteségi tartalékalap szükségszerúségét ugyan nem vitatta, a 100 millió korona alapítási összeget túlzónak, sốt „lehetetlennek” tartotta, és ehelyett inkább telepítési célokra (pl. Erdélyben, Moldovában, Bukovinában, Amerikában élô magyarok hazatelepítésére) javasolta fordítani ezen összeget. Egyes képviselők a Pénzintézeti Központ alapításának javaslata elôtt is értetlenül álltak, és nem csekély gúnnyal a pénzügyminiszter „kedvenc intézményének” nevezve szintén más felhasználást szántak az alapítási összegnek. Tisza István ugyanakkor a Pénzintézeti Központ mielőbbi létrehozását sürgette, álláspontja szerint - mely a késôbbi, gazdasági válság során bekövetkezett körülmények ismeretében megalapozottnak bizonyult - az elsô világháborút követôen rendkívül nagy szükség lesz, hogy „a magyar közgazdaságnak rendelkezésére (álljon) akkor, amidôn az a háború megszúnte után igen nagy krízisen fog átmenni, és rend- 
kívüli feladatok, egy teljesen rendkívüli helyzetnek ma még beláthatatlan feladatai elé fog állíttatni”. ${ }^{2}$

Az elsố világháború idôszakában a gazdaság számos területén (pl. termelés, anyagellátás) szükségszerúen tapasztalható volt a korábbiaknál nagyobb fokú állami szerepvállalás az allokáció tekintetében, így ezen tendencia pénzügyi intézményrendszerre történó esetleges kiterjesztése is megjelent félelemként (Varga, 2019). Ezek adhattak okot arra, hogy Apponyi Albert miniszter, az MTA tagja, tartván a Pénzintézeti Központ tagintézményeit érintô túlzott politikai nyomás gyakorlásától, a leghatározottabban tiltakozott a Pénzintézeti Központ alapítására vonatkozó törvényjavaslat benyújtása ellen. Tiltakozásában továbbá a Pénzintézeti Központ alapításával kapcsolatos vélemények megosztottságára is rávilágított. ${ }^{3}$ Földes Béla egyetemi tanár, miniszter, az MTA tagja, valamint a budapesti egyetem késôbbi rektora szerint a Pénzintézeti Központ létesítése kapcsán felmerüló politikai szempontok nem kizárólag pártpolitikai, hanem többek között gazdaságpolitikai és hitelpolitikai vonatkozásban is értendóek. Kifejezést adott azon álláspontjának, hogy a Pénzintézeti Központ létrehozása nagy vonalakban megfelel az államosítás koncepciójának, továbbá annak létrehozásával az állam hiteléletre való befolyása várhatóan nagyobb mértékben fog érvényesülni, mint az kívánatos lenne. Ezzel összefüggésben az állami beavatkozás optimális szintjének meghatározása is a viták tárgyát képezte.

További vita bontakozott ki az ellenórzés módja felől a tekintetben, hogy az milyen intézményi körre terjedjen ki. Legtöbb képviselóje annak a javaslatnak volt, amely szerint az ellenőrzés köre kizárólag azon kisebb pénzintézetekre terjesztendó ki, melyek hitelt vesznek igénybe a Pénzintézeti Központtól, vagy maguk kérik az ellenórzés lefolytatását. E javaslatot támogatta az a körülmény is, hogy a Pénzintézeti Központ, különösen múködése korai időszakában, egyébként sem rendelkezett kellôen nagyszámú vizsgáló munkavállalóval, akik minden tagintézetre vonatkozóan el tudták volna végezni a vizsgálatokat. Az előre nem meghatározott, bizonyos szempontok szerinti kiválasztás alapján folytatott vizsgálatoknak viszont a vélemények szerint bizalmatlanságnövelô hatása lett volna. A törvényjavaslat országgyúléshez történô beterjesztését követôen több esetben ellenállás mutatkozott a javaslattal kapcsolatban, mert - Apponyi véleményével összhangban - a Pénzintézeti Központ intézményében rejtett politikai célokat, a kormány hatalmának kiterjesztését, a veszteségi tartalékalap létrehozásában pedig kizárólag pártpolitikai célok megvalósítását látták (pl. adósságok rendezése). Ezt a véleményt a Pénzintézeti Központ alapszabályának elkészülte sem változtatta meg, melynek 58. §-a részletesen tartalmazta a veszteségi tartalékalap rendeltetését. Ezért a Pénzintézeti Központ létrehozásának feltételeként az alapszabály törvénybe iktatását és a veszteségi tartalékalap felhasználásának ellenzék számára történô megtekinthetôségét határozták meg.

A nemzeti munkapárti programmal országgyúlési képviselônek megválasztott Antal Géza 1916. január 3-án tartott beszédében a Pénzintézeti Központ létrehozását támogatandó, hivatkozott a korábban létrehozott Magyar Takarékpénztárak Központi Jelzálogbankjának tevékenységére, melynek felügyeleti feladatai is voltak a kötelékébe tartozó, elsôsorban vidéki takarékpénztárak vonatkozásában. Antal érvelése szerint 
ugyanis a békeidóben fontos és általánosan elismert, szintén egyfajta „pénzintézeti központ” szerepét betöltô Jelzálogbankhoz hasonló intézményre a háborús viszonyok között még inkább szükség van. Álláspontja szerint a pénzintézetek többsége egyenesen tart a moratórium eltörlésétôl a várhatóan növekvố hiteligények és a betétek esetleges kivétele következtében. A betétek idôszaki növekedésével kapcsolatban kifejezte, hogy az nem a gazdaság megfeleló múködésének vagy a pénzintézeti szektorba vetett bizalom erôsödésének tudható be, hanem éppen arra utal, hogy a gazdaság nem tölti be megfelelóen a szerepét. Szerinte az ügyfelek mindössze ideiglenesen helyezik el a pénzintézeteknél a betéteket egészen addig, amíg a gazdasági helyzet normalizálódásával, a gazdasági fellendüléssel párhuzamosan azokat a különbözó kereskedelmi és ipari vállalkozásokba át nem lehet helyezni. Ezen gondolatmenetet folytatva tehát a háború befejezése után, amikor a hitelszükséglet növekedése várható, a korábbiakhoz képest nagyobb szükség lesz a Jelzálogbankhoz hasonló „pénzintézeti központ” múködésére. Ráadásul a gazdaság várható felfelé ívelése során a Pénzintézeti Központ anyagi szerepe mellett elôtérbe kerülhet annak erkölcsi szerepe is, hiszen a revíziók lefolytatásával ösztönzô erôként hathat a prudensebb magatartás gyakorlására.

Teleszky János hangsúlyozta, hogy a Pénzintézeti Központ alapításának célja abban foglalható össze, hogy lehetôség szerint minél több pénzintézetet ellenőrzés alá vonva járuljon hozzá a szektor biztonságos múködéséhez, ezáltal a betétesek érdekeinek védelméhez. Aggodalmát fejezte ki azzal összefüggésben, hogy a Pénzintézeti Központ átmeneti időre történô létrehozásával vélhetően nehezebb lesz megfelelő szakembereket találni, illetôleg ebben az esetben biztosítani kell számukra, hogy az intézmény esetleges megszúnése esetén a szakemberek megfeleló illetményben részesüljenek. Elmondta továbbá, hogy a növekvô bizalmatlanság leküzdése érdekében hozzájárul az Alapszabály törvénybe való beiktatásához, hozzátéve, hogy ebben az esetben meglehetôsen nehéz lesz annak módosítása, amire adott esetben szükség lehet a Pénzintézeti Központ múködési hatékonyságának növeléséhez.

\section{A Pénzintézeti KözPONT TEVÉKenYségét érintô Viták AZ 192O-AS ÉVEKBEN}

A Pénzintézeti Központ tevékenységi körében idôvel megjelentek olyan feladatok is, amelyek nem vagy csak részben kapcsolódtak pénzügyi intézményekhez. Ehhez alapot szolgáltatott a Pénzintézeti Központról szóló 1920. évi XXXVII. törvénycikk, mely alapján az részt vehet közhasznú és közérdekú vállalkozásokban, és közremúködhet közgazdasági célú intézmények pénzügyi és adminisztratív ügyeinek intézésében. ${ }^{4}$ Ennek keretében számos iparvállalat alapításában töltött be kezdeményezó szerepet, például az 1925-ben alapított Fuvarhitelintézet Rt. esetében, mely létrehozásának egyik fố célja a záloggal fedezett fuvarhitelezési forgalom bevezetése volt. Emellett részt vett a Molinum Malomipari Rt. alapításában (Jenei, 1970), továbbá az intézmények alapításának kezdeményezéséhez, ügykezeléséhez kapcsolódóan azokban sok esetben részesedéssel is rendelkezett. A Pesti Victoria Gốzmalom és az érdekeltségi körébe tartozó malomvállalatok (mintegy 23 vállalat) fizetésképtelenségét megaka- 
dályozandó, szanálás lebonyolítására az 1926. évben szintén a Pénzintézeti Központot jelölték ki (Jakabb et al., 1941). A szanálással összefüggó feladatok, a malomvállalatok rendelkezésére bocsátott anyagi támogatás jelentôsen igénybe vette a Pénzintézeti Központ erôforrásait. A Victoria Gốzmalom szanálásának rendkívül nagy jelentôsége volt, hiszen az érdekeltségi körébe tartozó hódmezóvásárhelyi Bauer-malom, melynek órleményei (nem utolsósorban a helyi búza kiemelkedóen magas sikértartalmának köszönhetôen) akkoriban nemcsak hazai, hanem európai szintú összehasonlításban is magas színvonalúnak számítottak. ${ }^{5}$ A Pénzintézeti Központ szanálási tevékenységével kapcsolatban így nem meglepó módon jelentek meg kritikák, ti. hogy a Pénzintézeti Központ eredetileg a pénzintézetek, nem pedig egyéb vállalkozások (pl. újságkiadó vállalat vagy a gabonafélék forgalmazását ellátó Futura Rt.) szanálását túzte ki céljául, ezért ezek nem tekinthetôek alapszabályszerú tevékenységeknek. ${ }^{6}$ Megjelentek olyan vélemények is, melyek a Pénzintézeti Központ elszámoltathatóságának növelését tartották szükségesnek. ${ }^{7}$

Balogh Elemér, a Hangya Fogyasztási Szövetkezeti Központ későbbi elnöke a megjelent kritikákra reagálva egyfelől megerősítette, hogy a Pénzintézeti Központ számára biztosított forrásokból nem kizárólag a pénzintézetek, hanem a reálgazdaság szereplői is részesültek. Balogh ugyanakkor nem kárhoztatta, hogy a Pénzintézeti Központ eltávolodott létrehozásának eredeti céljától, hanem éppen ellenkezóleg, hangsúlyozta, hogy annak szanálási tevékenységén keresztül többek között az iparvállalatok, mezôgazdasági vállalatok helyreállításával közvetetten a pénzintézetek rentabilitásához is hozzájárul. Véleménye szerint így a Pénzintézeti Központ valójában - ebben a tekintetben legalábbis - nem eltávolodott eredeti céljától, hanem kibóvítve tevékenységi körét, éppen azt erôsítette meg. ${ }^{8}$

A Pénzintézeti Központ alapításakor megfogalmazott elgondolások előtérbe kerülését jelentette az 1926. évi XIII. törvénycikk, mely alapján kiszélesedett a vizsgálat alá vont intézmények köre, a Pénzintézeti Központ ugyanis felülvizsgálatot tarthatott a pénzváltóüzlettel foglalkozó kereskedelmi cégeknél, valamint értékpapír-kereskedôknél. ${ }^{9}$ A törvénycikk lehetôséget biztosított a Pénzintézeti Központ tagjainak, hogy ne kizárólag csôdhelyzet esetén, hanem olyan helyzetben is forrásokhoz jussanak, amikor hitelszükségletük kielégítése nehézségekbe ütközik. Pénzintézetekhez kapcsolódó feladatainak bővülését jelentette, hogy a pénzintézetek egyesülésének lebonyolításában a Pénzintézeti Központ jelentős mértékben közremúködött. ${ }^{10}$ Szintén a pénzintézetekhez köthetô feladataihoz tartozott, hogy a bankok konzorcium formájában történô kezességvállalásához is (az Országos Központi Hitelszövetkezettel közösen) bizonyos esetben viszontgaranciát vállalt (Botos, 1994). Például 1928-ban a megalakuló Magyar Export Intézet által felvett, egy amerikai pénzcsoport részérôl folyósított ötmillió dollár összegú hitel visszafizetéséért a pénzintézetek által vállalt kezességeket támasztotta alá viszontgaranciával. Az 1926. évi XIII. törvénycikkbôl elmaradt számos korábbi, az 1920. évi XXXVII. törvénycikkben szereplố rendelkezés, úgymint az állam hitelszükségleteinek kielégítésében, valamint a közérdekú és közhasznú vállalkozásokban való részvétel. Ugyanezen törvénycikk rögzítette, hogy további feladatot kizárólag törvényben lehet a Pénzintézeti Központ részére elôírni. ${ }^{11}$ A Pénzintézeti Központ feladatkö- 
rének további kiterjesztésére vonatkozóan is született javaslat. Székács Antal, a Kereskedelmi és Iparkamara késôbbi alelnöke 1930-ban javasolta, hogy valamennyi községi üzem a Pénzintézeti Központ ellenőrzése alá tartozzon annak érdekében, hogy ezen üzemek múködésének a létjogosultsága, gazdálkodása, valamint a magángazdaságra gyakorolt hatása megállapítható legyen. Véleménye szerint a közüzemek tevékenysége nem teljes mértékben felelt meg a közérdeknek, az általa nyújtott termékek, szolgáltatások pedig alacsony áruk és gyengébb minôségük folytán kedvezôtlen hatást gyakoroltak a magángazdaságra, múködésüket veszélyeztetve. ${ }^{12}$ A javaslat elfogadására ugyanakkor nem került sor, a kialakult általános vélemény szerint Székács szavai túlzónak bizonyultak, mivel a közüzemek magángazdaságra gyakorolt hatása közel sem volt jelentôs mértékú, továbbá külön ellenôrzésre nem volt szükség, ugyanis a közüzemek az 1930. évi XVIII. törvénycikk alapján a kormányhatóság felügyelete alá tartoztak, és a kormányhatóság a 92. § (6) bekezdés alapján az adott közüzem megszüntetését elrendelhette, amennyiben annak múködése nem volt gazdaságos, vagy nem a közérdeket szolgálta. Javaslat született arra vonatkozóan is, hogy a gabona-jelzálogkölcsönök folyósítására alakult vállalkozások engedélyezése kapcsán a Pénzintézeti Központ a döntéshozatalt megelôzően kérje ki a Kereskedelmi és Iparkamara véleményét. ${ }^{13}$ Széll Gyula képviselő felhívta a figyelmet azon jelenségre, hogy egyes pénzintézetek az ingatlanárveréseken spekulációs célból feltúnóen sok alkalommal jutnak hozzá ingatlanokhoz, meglehetősen kedvezó áron. Széll ennek kapcsán javasolta, hogy a Pénzintézeti Központ folytasson ellenőrzést az érintett pénzintézeteknél, és adott esetben hívja fel a figyelmet az ehhez hasonló gyakorlat jövóbeni elkerülésére. ${ }^{14}$ A javaslatot végeredményben a Pénzintézeti Központ felülvizsgálati funkciójának későbbi kiterjesztésével együtt figyelembe vették.

\section{KÉSÓB BI VITÁK, JAVASLATOK A FELÜGYELÉS MEgÚJíTÁSÁRA VONATKOZÓAN}

A Pénzintézeti Központ feladatainak bôvülésével 1931-re szükségessé vált alaptôkéjének emelése, mellyel összefüggésben szintén heves viták bontakoztak ki. A közel 24 millió pengó összegú tôkeemelést (elsôsorban az Országos Központi Hitelszövetkezet, a Kisbirtokosok Országos Földhitelintézete, az Iparosok Országos Központi Szövetkezete, valamint több altruista bank tôkehelyzetének megszilárdítására) ugyanis többen túlzónak tartották a hitelélet támogatását célzó beruházásokra összesen fordított 73 millió pengóhöz képest. Ezen álláspontok szerint a tôkeemelésre fordított összeget inkább a gazdaság más ágazatának (pl. infrastruktúra) támogatására lett volna szükséges fordítani. ${ }^{15}$ A Pénzintézeti Központ szanálási tevékenységével kapcsolatban megfogalmazott kritikák - hasonlóan az alapításkor felszínre került aggodalmakhoz - érintették az átláthatóság kérdéskörét is. Pakots József újságíró, író, az általa alapított Írók Gazdasági Egyesülete elnökének megfogalmazásában a példaként felhozott bécsi CA szanálása a parlamenti pártok hozzájárulásával, folyamatos ellenőrzés mellett zajlott, míg a Pénzintézeti Központ szanálási tevékenységére elkülönített 33 millió pengố felhasználásának módja véleménye szerint nem kapott megfelelő, nyilvános figyelmet. ${ }^{16}$ 
A Pénzintézeti Központ által folytatott vizsgálatok nem megfelelő hatékonyságára utalt többek között Andaházi-Kasnya Béla országgyúlési képviseló, késóbbi törökországi nagykövet is, aki kifogásolta, hogy a Pénzintézeti Központ által a Magyar Bankegyesület Részvénytársaságnál az osztálysorsjátékok kezelésével kapcsolatban feltárt visszaélések, spekulációs tevékenység ellenére hathatós intézkedést nem tett. Andaházi-Kasnya ugyanis nem tartotta elegendónek, hogy a Pénzintézeti Központ a Bankegyesületnek megtiltotta a sorsjegyek árusítását, tevékenységi engedélyének visszavonását javasolta. ${ }^{17}$ Megfogalmazódtak kritikai vélemények a Pénzintézeti Központ jelentéseire vonatkozóan is. Eckhardt Tibor kisgazdapárti politikus a Pyramis Földbirtokosok és Földbérlők Rt. és érdekkörébe tartozó társaságokkal szemben lefolytatott vizsgálati eljárást lezáró jelentést - miután a korábban megindult búnvádi eljárást a vizsgálat megszüntetô végzéssel zárta le - „tarthatatlannak” nevezte, továbbá kifogásolta, hogy egy ilyen, komoly károkat jelentô ügyben véleménye szerint a Pénzintézeti Központ könnyedén járt el. ${ }^{18}$

Számos javaslat született a Pénzintézeti Központ tevékenységének további kiterjesztésére is. Szilágyi Lajos képviselő, Bihar vármegye korábbi fơispánja az ebben az idôszakban múködő több mint ezer egyesülettel kapcsolatban kritikaként fogalmazta meg, hogy ezek pénzügyi ellenôrzés nélkül múködnek, valamint indítványozta az életképtelen egyesületek megszüntetését, az életképes egyesületek lehetôség szerinti öszszevonását. Javasolta továbbá, hogy az egyesületek egy ún. csúcsintézmény kötelékébe szervezôdjenek, mely intézmény az egységes pénzkezelés érdekében kezelje az egyesületek pénzállományát. E feladatok ellátására Szilágyi a Pénzintézeti Központot ajánlotta kijelölésre. ${ }^{19}$ Béldi Béla, a siklósi választókerület országgyúlési képviselóje a megjelenô félelmekkel kapcsolatban - miszerint a kisebb pénzintézetek múködése nem kellôen prudens a betétesek megtakarításainak biztonságos elhelyezéséhez - 1938-ban szorgalmazta, hogy a Pénzintézeti Központ töltsön be egyfajta garanciaintézmény-szerepet. Érvelését azzal támasztotta alá, hogy a Pénzintézeti Központnak ellenôrzései révén tudomással kell bírnia a pénzintézetek tevékenységéról, így - amennyiben felülvizsgálati feladatait megfelelóen látja el - feladatkörébe értelemszerúen beletartozhat, hogy ilyenformán, esetleg elôre meghatározott garanciadíj ellenében, felelôsséget vállaljon az általa elvégzett ellenôrzések után. ${ }^{20}$ Árvátfalvi Nagy István, a Hadirokkantak, Hadiözvegyek és Hadiárvák Országos Nemzeti Szövetségének (HONSZ) elnöke pedig azt javasolta, hogy a megfelelő árvédelem biztosítása érdekében a Pénzintézeti Központ a kartelleket is vonja vizsgálat alá, egyfajta versenyhivatali feladatot is ellátva. ${ }^{21}$

A Pénzintézeti Központ hatáskörének kibővítésével összefüggésben szintén jelentôs polémiák alakultak ki a szakmai fórumokon. Árvátfalvi Nagy István, illetôleg Dinnyés Lajos kisgazdapárti politikus, késóbbi miniszterelnök is fontosnak tartotta a Pénzintézeti Központ ellenôrzésének kiterjesztését elsôsorban a betétesek érdekeinek védelme érdekében. ${ }^{22}$ 1938-ban Rajniss Ferenc képviselő, késôbbi vallás- és közoktatásügyi miniszter a Rimamurány-Salgótarjáni Vasmú esetében előforduló visszaéléssel és a kapcsolódó pénzintézeti érintettséggel összefüggésben kritikaként megjegyezte, hogy számos pénzintézet (és nagyvállalat) nem tartozik a Pénzintézeti Központ vizsgálati körébe, mindössze kisebb intézmények tartoznak a felügyelete alá. ${ }^{23} \mathrm{El}$ nem 
fogadott javaslat is született a Pénzintézeti Központ tevékenységének kibővítésére, ti. Sulyok Dezsố politikus, Pápa város polgármestere javasolta, hogy mindazon ipari és kereskedelmi vállalatok, amelyek állami támogatásban vagy kedvezményben részesülnek (pl. vámvédelem, adóelengedés, adómérséklés), ugyanolyan kötelezô jellegú felülvizsgálat alá tartozzanak, mint a pénzintézetek. ${ }^{24}$ Olyan indítvány is elhangzott, amely a községi üzemek ellenôrzését is a Pénzintézeti Központhoz rendelte volna. ${ }^{25}$ Az 1930-as évek közepétôl felerôsödtek a Pénzintézeti Központ hatáskörének kibôvítését szorgalmazó javaslatok. Lichtenstein László, Miskolc fóispánja például 1936-ban azt ajánlotta, hogy valamennyi pénzintézet, tekintet nélkül a kúriába való tartozásra, a Pénzintézeti Központ tagintézményeinek körébe tartozzon. ${ }^{26}$ Ehhez kapcsolódóan kifogás elsôsorban a Pénzintézeti Központ apparátusára vonatkozóan érkezett, vagyis hogy az nem elegendô valamennyi pénzintézet tevékenységének ellenôrzésére. ${ }^{27}$

\section{ÖsszegZÉS}

Számos, különbözó fórumokon zajlottak le viták a 20. század elsố felében a felügyelésre vonatkozóan, melyek több hibára, nem megfelelố tendenciára is rávilágítottak (például túlzottan kiterjedt tevékenységi kör, eredeti elgondolásoktól eltávolodott tevékenység, nem elegendô alkalmazotti létszám). A viták, véleményütköztetések azonban nem voltak hiábavalóak, hiszen számos javaslat beépült a Pénzintézeti Központ tevékenységének késôbbi módosításai során, hozzájárulva a felügyelés sikerességének, végsố soron pedig a pénzügyi rendszer ellenálló képességének növeléséhez.

Korányi Frigyes pénzügyminiszter, a Pénzintézeti Központ 1928-ban kinevezett elnöke az intézmény válságban betöltött szerepét a következókben értékelte: „Ami a Pénzintézeti Központot illeti, annak a jelenlegi válság alatt kifejtett múködése a legnagyobb elismerésre méltó. Jóllehet tőkéje egynegyedét sem teszi annak, amelyet a törvényhozás számára annak idején megállapított, és az előzô kormánynak már nem állott módjában tôkéjét a közeledô válságra való tekintettel tervezett emeléssel megerôsíteni, s bár mintegy 500 pénzintézet tartozik kötelékébe, amelyek túlnyomó része igénybe vette a válság alatt irányító tanácsait és anyagi segítségét, nagyrészt a Pénzintézeti Központ múködésének tulajdonítható, hogy a válság elején mutatkozott nagymérvú betételvonásokkal szemben a pénzintézetek képesek voltak helyüket megállani, kivéve azt az aránylag kevés számú intézetet, amely hibás vezetés vagy létének indokolatlan volta folytán kényszerül csendes felszámolásra..."28

Végezetül érdemes megemlítenünk az irodalmi munkásságot is folytató kiváló statisztikusnak, a Központi Statisztikai Hivatal harmadik elnökének, Vargha Gyulának a felügyelésre vonatkozó, napjainkban is érvényes szavait, mely egyaránt szemlélteti a hitelellátás, finanszírozás fontosságát: „Nem értünk az ellenôrzés alatt állami gyámkodást. A hitel szabad mozgást kíván. Korlátolva, megkötve elsorvad. Pedig a hazai hitelnek nem szabad elsorvadnia; buzogjon fel minél dúsabb forrásokban, és termékenyítse meg ezt a földet, hogy felvirágozzék rajta a földmivelés, ipar és kereskedelem, nemzetünk pedig gyarapodjék a jólétben és vagyonosodásban, hogy ellenállhasson az idôk minden viharának" (Vargha, 1885:194). 


\section{JEGYZETEK}

1 Jelen cikk a szerzố nézeteit tartalmazza, és nem feltétlenül tükrözi a Magyar Nemzeti Bank hivatalos álláspontját.

2 Képviselôházi napló, 1915. december 11.

3 Képviselőházi napló, 1915. december 21.

4 1920. évi XXXVII. törvénycikk a Pénzintézeti Központról, 1. § (7) bekezdés alapján.

5 Országgyúlési napló, 1931. december 17.

6 Képviselôházi napló, 1928. május 25.

7 Képviselôházi napló, 1927. április 1.

8 Országgyúlési napló, 1928. március 22.

9 1926. évi XIII. törvénycikk a Pénzintézeti Központról szóló 1920:XXXVII. törvénycikk egyes rendelkezéseinek módosításáról, 1. § (1) bekezdés alapján; korábban ezen feladatokat az 1300/1923. sz. PM rendelet, illetve a 6700/1923. sz. PM rendelet bízta a Pénzintézeti Központra, melyek törvényben való rögzítése annak szervezeti és funkcionális megerôsödésére utal.

10 1926. évi XIII. törvénycikk a Pénzintézeti Központról szóló 1920:XXXVII. törvénycikk egyes rendelkezéseinek módosításáról, 1. § (4) bekezdés alapján.

11 1926. évi XIII. törvénycikk a Pénzintézeti Központról szóló 1920:XXXVII. törvénycikk egyes rendelkezéseinek módosításáról, 1. § (7) és (12) bekezdések alapján.

12 Országgyúlési napló, 1930. május 13.

13 Országgyúlési napló, 1930. július 8.

14 Országgyúlési napló, 1932. június 27.

15 Országgyúlési napló, 1931. augusztus 1.

16 Országgyúlési napló, 1931. november 24.

17 Országgyúlési napló, 1932. február 17.

18 Országgyúlési napló, 1932. június 1.

19 Országgyúlési napló, 1938. április 9.

20 Országgyúlési napló, 1938. június 22.

21 Országgyúlési napló, 1938. május 23.

22 Képviselőházi napló, 1938. május 23.

23 Képviselôházi napló, 1938. december 14.

24 Képviselôházi napló, 1938. április 6.

25 Képviselôházi napló, 1930. május 13.

26 Képviselôházi napló, 1936. május 8.

27 Képviselőházi napló, 1938. május 19.

28 Országgyúlési napló, 1932. április 5.

\section{FELHASZNÁLT IRODALOM}

Blum Brúnó (1899): Pénzgazdaságunk és a vidéki intézetek. Közgazdasági Szemle, 23. évf., 740-764.

Botos János (1994): A magyarországi pénzintézetek együttmúködésének formái és keretei. Közgazdasági és Jogi Könyvkiadó, Budapest.

Hantos Elemér (1916): A pénzintézeti reform: A Pénzintézeti Központ törvényének és alapszabályainak jegyzetes szövegével. 2. bôvített kiadás, Pénzintézetek Országos Egyesülése, Budapest.

Jakabb Oszkár - Reményi-Schneller Lajos - Szabó Iván (1941): A Pénzintézeti Központ elsô huszonöt éve (19161941). Királyi Magyar Egyetemi Nyomda, Budapest.

Jenei Károly (1970): A Pénzintézeti Központ szerepe a Magyar Tanácsköztársaság bankrendszerében. A Magyar Történelmi Társulat Üzemtörténeti Szekciójának kiadványa. Különlenyomat a Levéltári Közlemények 40. évfolyamából, 37-55. 
Varga Bence: Viták a hazai pénzügyi felügyelés megújításáról a 20. század elsố felében

Kandrács Csaba (2019): A bankfelügyelés megújulása. Polgári Szemle, 15. évf., 1-3. sz., 92-115. https://doi. org/10.24307/psz.2019.0906.

Kovács György - Varga Bence (2018): Lehetetlenségi trilemmák előfordulása a magyar gazdaságtörténetben (1867-1938). Pénzügyi Szemle, 63. évf., 1. sz., 113-129.

Lentner Csaba (2019): A magyar állampénzügyek fejlôdéstörténete a dualizmus korától napjainkig. L'Harmattan Kiadó, Budapest.

Sugár Ignác (1899): Pénzintézetek reformja. Közgazdasági Szemle, 23. évf., 403-425.

Székely Ferenc (1890): Takarékpénztáraink reformja. Nemzetgazdasági Szemle, 14. évf., 4. füzet, 309-317.

Varga Bence (2016a): 100 éve alakult a Pénzintézeti Központ. Hitelintézeti Szemle, 15. évf., 1. sz., 124-144.

Varga Bence (2016b): A magyar bankfelügyelés megszervezése (19. század második fele - 20. század eleje). Gazdaság és Pénzügy, 3. évf., 1. sz., 61-80.

Varga Bence (2019): A pénzügyi felügyelés kialakulása Magyarországon. Lehetetlenségi trilemmák előfordulása a hazai felügyelettörténetben. Doktori értekezés, Szegedi Tudományegyetem, Közgazdaságtani Doktori Iskola, Szeged.

Vargha Gyula (1885): Magyarország pénzintézetei. Visszapillantás hitelviszonyaink fejlödésére és hazai pénzintézetek négy évtized alatti múködésére. Pesti Könyvnyomda Rt., Budapest. 